\title{
KESIAPAN BELAJAR SISWA TUNARUNGU YANG MENEMPUH PENDIDIKAN INKLUSI
}

\author{
Bagus Cakraningrat, Fuadah Fakhruddiana \\ Fakultas Psikologi Universitas Ahmad Dahlan \\ Jl. Kapas No.9 Semaki, Yogyakarta \\ cakraningratbagus@gmail.com \\ fakhruddiana@gmail.com
}

\begin{abstract}
This research aims to know the deaf student readiness who took inclusive education to learn and to know the condition that supports and hampers it. This research used quantitative method by case approach. The data were collected by interview and documentation study. Content analysis was conducted to analyze the data. According to the result of the research, it can be concluded that both of the subjects could be said ready for the exam at inclusive school. The supportive factors of the deaf students readiness are parents' attention giving, cooperative teachers and friends' help while the inhibiting factors that hamper their readiness are more to the technical problems such as lack of literacy ability that cause difficulties in understanding the lesson.
\end{abstract}

Keywords : deaf, inclusive education, study readiness

\begin{abstract}
Abstrak
Tujuan penelitian ini adalah untuk mengetahui kesiapan belajar siswa tunarungu yang menempuh pendidikan inklusi serta mengetahui kondisi yang mendukung dan menghambat kesiapan belajar siswa tunarungu yang menempuh pendidikan inklusi. Metode penelitian yang digunakan dalam penelitian ini adalah metode kualitatif dengan pendekatan studi kasus. Teknik pengumpulan data dalam penelitian ini adalah menggunakan metode wawancara dan studi dokumentasi. Analisis data yang digunakan dalam penelitian ini adalah analisis isi (content analysis). Dari hasil penelitian yang diperoleh, dapat disimpulkan bahwa kedua subjek dapat dikatakan siap menempuh pendidikan di sekolah inklusi. Faktor pendukung kesiapan belajar dua subjek tunarungu yang menempuh pendidikan inklusi adalah perhatian orang tua, guru yang kooperatif, dan teman-teman yang membantu. Sedangkan faktor penghambatnya adalah lebih pada hal-hal teknis (kurangnya kemampuan berbahasa, sehingga kesulitan memahami pelajaran).
\end{abstract}

Kata kunci : kesiapan belajar, pendidikan inklusi, tunarungu 


\section{Pendahuluan}

Anak berkebutuhan khusus (ABK) merupakan anak yang memiliki hambatanhambatan tertentu yang berbeda dengan anak yang lainnya. Salah satu ABK adalah anak yang mengalami gangguan pendengaran atau yang biasa disebut dengan tunarungu. Menurut Winarsih (2007), seseorang yang tunarungu adalah seseorang yang mengalami kekurangan atau kehilangan kemampuan mendengar baik sebagian maupun seluruhnya yang diakibatkan oleh tidak berfungsinya sebagian atau seluruh alat pendengaran. Anak tunarungu tidak dapat menggunakan alat pendengarannya dalam kehidupan sehari-hari, hal ini berdampak terhadap kehidupannya secara kompleks terutama pada kemampuan bahasa sebagai alat komunikasi yang sangat penting (Winarsih, 2007).

Individu/anak dengan kemampuan pendengaran yang kurang, seringkali terisolasi dari orang-orang di sekelilingnya baik di rumah, sekolah, tempat bekerja, dan masyarakat (Fusick, 2008). Anak tunarungu dengan keterbatasannya juga berhak mendapatkan pendidikan seperti anak lainnya, anak-anak tersebut mempunyai hak yang sama dalam memperoleh pendidikan dan layanan-layanan dari pemerintah serta bantuan dari masyarakat. Pasal 5 UndangUndang Nomor 20 tahun 2003 tentang Sistem Pendidikan Nasional menyatakan bahwa "setiap warga negara mempunyai hak yang sama untuk memperoleh pendidikan yang bermutu" (Pemerintah RI, 2010). Sistem sekolah umum siswa dengan kekurangan pendengaran dapat memilih belajar via inklusi, pendidikan khusus, atau pelayanan khusus yang mendukung (Fusick, 2008). Menurut Dirjen PLB (2006) pendidikan inklusif merupakan sistem penyelenggaraan pendidikan yang memberikan kesempatan kepada semua peserta didik dari berbagai kondisi dan latar belakang untuk mengikuti pendidikan atau pembelajaran dalam satu lingkungan pendidikan secara bersamasama, dengan layanan pendidikan yang disesuaikan kebutuhan dan kemampuan peserta didik. Model yang diberikan sekolah inklusif ini menekankan pada keterpaduan penuh, menghilangkan keterbatasan dengan menggunakan prinsip education for all (Smart, 2010).

Dunia anak-anak berkebutuhan khusus terutama anak tunarungu banyak dikenal dengan sebutan dunia segregatif, dimana anak-anak tunarungu hanya bersekolah di sekolah khusus (SLB-B), yang ratarata siswanya hampir memiliki diagnosis yang sama. Di sekolah inklusif, anak-anak tunarungu ini akan diperkenalkan dengan dunia yang sebenarnya dimana latar belakang siswa sangat beragam sehingga heterogenitas terasa sangat kental. Menurut Gray, Hosie, Russell, \& Ormel (2001) inklusi yang sukses bagi anak-anak bisu dan tunarungu juga tergantung dari bagaimana mereka dapat menyesuaikan diri secara emosi dan sosial terhadap lingkungan (Thagard, Hilsmier, \& Easterbrooks, 2011). Seorang anak yang tidak memiliki kesiapan untuk belajar di sekolah inklusi akan mengalami hambatan dalam menjalani proses belajar. Menurut Slameto (2013) kesiapan sebagai faktor yang mempengaruhi proses belajar memiliki pengertian sebagai berikut, kesiapan adalah kesediaan untuk memberikan respon atau reaksi. Kesediaan itu timbul dari dalam diri seseorang dan juga berhubungan dengan kematangan, karena kematangan berarti kesiapan untuk melaksanakan kecakapan. Kesiapan ini perlu diperhatikan dalam proses belajar, karena jika seseorang itu belajar dan memiliki kesiapan maka hasil belajarnya akan optimal. 
Salah satu permasalahan dalam sekolah inklusi adalah kesiapan belajar. Kesiapan ditunjukkan oleh anak dengan merespon positif terhadap sekolah yang mendukung proses belajarnya seperti metode pembelajaran, tersedianya sarana dan prasarana untuk anak dengan tunarungu, penerimaan guru dan teman di sekolah, serta dukungan yang besar dari orang tua. Pendidikan inklusif dirasa belum maksimal karena belum memadainya kualitas guru bagi siswa berkebutuhan khusus. Dinas Pendidikan Provinsi DIY sendiri baru menyediakan 132 GPK (Guru Pembimbing Khusus) untuk sekolah-sekolah inklusi. GPK diambil dari SLB, dan hanya mendampingi dua kali dalam seminggu (Suara Merdeka). Siswa yang memiliki kebutuhan khusus harus didampingi setiap hari. Permasalahan yang dihadapi oleh siswa tunarungu diakibatkan karena adanya keterbatasan komunikasi dalam proses belajar. Guru diharuskan untuk menghadapkan wajahnya kepada mereka saat berbicara, serta harus menulis dengan jelas, sedangkan banyak siswa lain yang juga tidak boleh diabaikan. Banyak orang tua yang terlalu memaksakan anaknya yang memiliki tunarungu untuk bersekolah di sekolah inklusi, karena merasa pilu dan malu untuk menyekolahkan anaknya di SLB, padahal kenyataannya anak tersebut belum mampu untuk bersekolah di sekolah inklusi. Hal ini dapat mempengaruhi kesiapan peserta didik yang memiliki tunarungu dalam menempuh pendidikan inklusi sehingga mencapai hasil belajar yang baik.

Slameto (2013) mengemukakan kesiapan adalah keseluruhan kondisi seseorang yang membuatnya siap untuk memberi respon atau jawaban dengan cara tertentu terhadap suatu situasi. Menurut Djamarah (2011) kesiapan untuk belajar merupakan kondisi diri yang telah dipersiapkan untuk melakukan suatu kegiatan. Tiga aspek yang mempengaruhi kesiapan yaitu: (a) kondisi fisik, mental, dan emosional; (b) kebutuhan atau motif tujuan; (c) keterampilan dan pengetahuan yang telah dipelajari (Slameto, 2013). Slameto (2013) juga memaparkan faktorfaktor yang mempengaruhi kesiapan belajar, yaitu: (a) faktor keluarga; (b) faktor sekolah yang terdiri dari guru, sumber belajar, dan keadaan ruang kelas; (c) faktor lingkungan.

Berdasarkan teori ekologi menurut Urie Bronfenbrenner (Berns, 2004) struktur mikrosistem menjadi masukan interaksi langsung dengan agen-agen sosial (social agents) yang berkembang baik. Anak akan berinteraksi dalam suatu lingkungan atau komunitas yang signifikan seperti merespon sikap dari guru, persahabatan, dukungan bagi siswa, dukungan untukguru, kepemimpinan, administrasi, kurikulum, penilaian, program, keterlibatan orang tua dan keterlibatan masyarakat, sehingga persiapan terbaik bagi siswa yang menempuh pendidikan inklusi adalah interaksi anak secara aktual di dalam kelas. $\mathrm{C}$ ara yang paling bagus demi pencapaian pengertian dan kerjasama yang besar adalah keterlibatan siswa yang disertai dengan dukungan yang positif (Smith, 2006). Proses menuju kesiapan memiliki pengaruh dari dalam maupun dari luar, sehingga siswa dikatakan siap apabila mampu untuk merespon positif terhadap lingkungan tempat siswa berada.

Berdasarkan permasalahan dan pemaparan para ahli di atas, peneliti tertarik untuk meneliti kesiapan belajar siswa tunarungu yang menempuh pendidikan inklusi serta faktor pendukung dan penghambat dalam proses pembelajarannya. Rumusan masalah dalam penelitian ini adalah bagaimana kesiapan belajar siswa tunarungu yang menempuh pendidikan inklusi serta kondisi apa saja yang 
mendukung dan menghambat kesiapan belajar siswa tunarungu yang menempuh pendidikan inklusi.

\section{Metode Penelitian}

Pendekatan yang digunakan dalam penelitian ini adalah pendekatan kualitatif dengan metode studi kasus. Menurut Bodgan dan Taylor (Moleong, 2010) metodologi kualitatif adalah prosedur penelitian yang menghasilkan data deskriptif kualitatif berupa kata-kata tertulis atau lisan dari orang-orang dan perilaku yang diamati. Hancock \& Algozzine (2006), menyatakan bahwa penelitian studi kasus adalah penelitian yang dilakukan terhadap suatu 'obyek', yang disebut sebagai 'kasus', yang dilakukan secara seutuhnya, menyeluruh dan mendalam dengan menggunakan berbagai macam sumber data.

Penggunaan metode penelitian kualitatif dengan pendekatan studi kasus ini, realitas mengenai kesiapan belajar siswa tunarungu yang menempuh pendidikan inklusi akan dipandang sebagai suatu hasil konstruksi pemikiran yang dinamis dan penuh makna. Sugiyono (2011) menyebutkan bahwa realitas dalam metode penelitian kualitatif merupakan konstruksi dari pemahaman terhadap semua data dan maknanya. Teknik pemilihan subjek menggunakan purposive sampling. Pemilihan metode purposif didasarkan pada pernyataan Poerwandari (2009) bahwa pengambilan sampel pada penelitian kualitatif harus disesuaikan dengan masalah dan tujuan penelitian. Subjek penelitian adalah siswa tuna rungu bawaan yang masuk dalam klasifikasi profound losses yang menempuh pendidikan inklusi, duduk di kelas VII dan sebelumnya menempuh pendidikan di SLB, diperoleh dua subjek dalam penelitian ini.
Metode pengambilan data yang dilakukan adalah dengan metode wawancara dan analisis dokumen. Data akan dianalisis dengan menggunakan teknik analisis isi (content analysis). Penelitian ini menggunakan wawancara dengan metode semi terstruktur yang termasuk dalam kategori in-depth interview dan dalam pelaksanaannya lebih bebas bila dibandingkan dengan wawancara terstruktur. Berdasarkan kondisi di lapangan subjek penelitian adalah siswa tunarungu, maka wawancara secara langsung tidak dapat digunakan untuk memperoleh data, sehingga digunakan metode wawancara secara tertulis dengan menggunakan media tulis, tatapi peneliti akan melakukan wawancara langsung kepada significant person, yaitu orang tua dan GPK dari subjek penelitian. Peneliti juga melakukan observasi pada saat subjek sedang belajar di dalam kelas dengan menggunakan metode observasi non partisipan untuk menambah kekuatan data. Metode studi dokumentasi yang digunakan peneliti diarahkan pada data hasil rapor kedua subjek saat menempuh pendidikan selama satu semester di sekolah inklusi.

Menurut Moleong (2010) data yang diperoleh dalam penelitian akan lebih diyakini kebenarannya jika ada dua sumber atau lebih menyatakan hal yang sama, oleh karena itu untuk mencapai kredibilitas penelitian, maka peneliti melakukan pendekatan triangulasi. Triangulasi yang digunakan dalam penelitian ini adalah triangulasi sumber dan triangulasi metode. Menurut Patton (Moleong, 2010) triangulasi sumber memiliki arti membandingkan dan mengecek ulang derajat keterpercayaan suatu informasi yang diperoleh melalui sumber yang berbeda dalam penelitian kualitatif. Triangulasi metode yaitu pengecekan terhadap derajat kepercayaan penemuan 
hasil penelitian dengan beberapa teknik pengumpulan data yaitu menggunakan metode wawancara dan studi dokumentasi.

\section{Hasil dan Pembahasan}

Kedua subjek dalam penelitian ini, mengalami tunarungu sejak kecil. Menurut klasifikasi yang dipaparkan oleh Streng (Haenudin, 2013), tunarungu yang dialami kedua subjek termasuk dalam klasifikasi profound losses, yaitu kehilangan kemampuan pendengaran $75 \mathrm{~dB}$ ke atas. Subjek pertama mengalami kehilangan kemampuan pendengaran sebesar $120 \mathrm{~dB}$ yang diakibatkan oleh adanya kelainan pada otak bagian kirinya, sedangkan subjek kedua mengalami kehilangan kemampuan pendengaran sebesar 98-99 dB yang diakibatkan oleh penyakit ketika dalam kandungan.

Kedua subjek sedang menempuh pendidikan di sebuah sekolah inklusi di Bantul, yaitu di SMP Negeri dan duduk di kelas VII, artinya subyek belum terlalu lama menempuh pendidikan inklusi. Model pendidikan inklusi yang diterapkan di SMP Negeri ini, berdasarkan pernyataan Vaughn, Bos \& Schumn (Direktorat Pembinaan Sekolah Luar Biasa, 2008) termasuk ke dalam kelas reguler dengan pull out; yaitu anak berkebutuhan khusus belajar bersama dengan anak lain di kelas reguler, namun dalam waktu-waktu tertentu ditarik keluar dari kelas reguler ke ruang bimbingan atau ruang sumber untuk belajar dan mendapat layanan bimbingan dari Guru Pembimbing Khusus. Kedua subjek sebelumnya menempuh pendidikan di sebuah SLB. Subjek pertama pernah bersekolah di SLB BSP, sedangkan subjek kedua pernah bersekolah di SLB Negeri.

Gangguan pendengaran yang dialami oleh kedua subjek ini terkadang mengakibatkan kedua subjek mengalami kesulitan dalam belajar di sekolah. Kesulitan belajar ini dikarenakan keterbatasan dalam kemampuan bahasa kedua subjek, sehingga sulit untuk bisa memaknai sebuah kalimat. Hal ini juga didukung oleh Efendi (2008) bahwa kehilangan pendengaran yang dialami anak tunarungu berdampak pada kemiskinan kosakata, kesulitan berbahasa dan berkomunikasi. Gangguan pendengaran juga pernah menyebabkan kedua subjek merasa malu dengan keadaannya. Berdasarkan hasil penelitian yang dilakukan oleh Solikhatun (2013), membuktikan bahwa interaksi sosial yang dilakukan penyandang tunarungu di lingkungan sosialnya menggambarkan bahwa dalam diri penyandang tunarungu cenderung memiliki rasa kurang percaya diri, minder, tidak mudah dekat dengan orang lain khususnya orang normal, tapi dengan berjalannya waktu, kedua subjek sudah mampu untuk beradaptasi dengan lingkungan inklusi tempat mereka bersekolah.

Kedua subjek memiliki motivasi dan kesungguhan dalam hal belajar, terlihat bahwa mereka selalu mengerjakan tugas yang diberikan oleh guru, selalu membawa pelajaran sesuai jadwal, selalu memperhatikan yang guru jelaskan di kelas dan selalu disiplin dalam hal belajar. Motivasi belajar merupakan kekuatan, daya pendorong, atau alat pembangun kesiapan dan keinginan yang kuat dalam diri siswa untuk belajar secara aktif, kreatif, efektif, inovatif, dan menyenangkan (Hanafiah, 2009).

Kedua subjek memiliki motif yang sama untuk belajar di sekolah inklusi, yaitu agar bisa belajar untuk bersosialisasi dengan orang normal, karena sebagai bagian yang integral dari masyarakat yang mendengar, anak tunarungu tidak dapat lepas dari nilai sosial yang berlaku dan harus dilaksanakan 
(Efendi, 2008). Subjek pertama, masuk ke sekolah inklusi adalah keinginannya sendiri, walaupun subjek sempat merasa menyesal ketika sudah masuk ke sekolah inklusi, tetapi dengan adanya dukungan dari orangtuanya, subjek bisa kembali percaya diri untuk tetap meneruskan pendidikan di sekolah inklusi. Subjek kedua, masuk ke sekolah inklusi adalah keinginan orangtuanya, karena orangtuanya menginginkan subjek untuk bisa belajar bersosialisasi dengan orang- orang normal dan subjek pun menyetujui keputusan orangtuanya.

Kedua subjek sebenarnya tidak memiliki masalah kognisi, tetapi keterbatasan yang dimiliki, terkadang menyebabkan subjek memperoleh nilai yang kurang memuaskan dalam ulangan, hal ini lebih sering terjadi pada subjek pertama dibandingkan dengan subjek kedua. Hasil rapor yang diperoleh oleh kedua subjek, bahwa subjek pertama masih memperoleh dua nilai dibawah standar KKM, seperti mata pelajaran IPA dan Seni Budaya dengan nilai 2.73 dari skala 4.00 dan dua nilai sama dengan KKM seperti mata pelajaran Penjaskes dan Bahasa Jawa dengan nilai 2.86 dari skala 4.00, sedangkan semua nilai subjek kedua sudah berhasil mencapai KKM, walaupun dengan nilai yang sama dengan standar KKM seperti mata pelajaran Bahasa Inggris dan Seni Budaya dengan nilai 2.86 dari skala 4.00. Pintner (Efendi, 2008), seorang psikolog yang bekerja pada lembaga pendidikan anak tunarungu mengemukakan, bahwa anak tunarungu hanya dapat menunjukkan kemampuan dalam bidang motorik dan mekanik, serta intelegensi konkret, tetapi memiliki keterbatasan dalam intelegensi verbal dan kemampuan akademik.

Kedua subjek juga memiliki keluarga yang sangat mendukung kegiatan belajar mereka. Bentuk dukungan yang diberikan oleh keluarga subjek pertama dan kedua tidak jauh berbeda. Bentuk dukungan yang diberikan pada subjek pertama berupa pemberian pemahaman terkait kondisi subjek, perhatian, bimbingan, kasih sayang, dan semangat ketika subjek merasa menyesal masuk ke sekolah inklusi, sedangkan pada subjek kedua, bentuk dukungan yang diberikan berupa dukungan tenaga, biaya, pikiran, bimbingan, perhatian dan usaha untuk memenuhi apa yang dibutuhkan dalam kegiatan belajar subjek. Dukungan positif yang diberikan untuk kedua subjek, membuat kedua subjek memiliki persepsi positif kepada keluarga yang menyebabkan kedua subjek memiliki kesiapan belajar yang baik.

Slameto (2013) mengemukakan bahwa perhatian dan bimbingan orang tua di rumah akan mempengaruhi kesiapan belajar siswa. Hal ini didukung dengan teori ekologi yang dipaparkan oleh Urie Bronfrenbrenner (Berns, 2004) yang mengungkapkan bahwa keluarga sebagai mikrosistem, adalah suasana yang memberikan pemeliharaan, kasih sayang, dan berbagai kesempatan yang memiliki dampak signifikan terhadap perkembangan kesiapan belajar anak.

Sekolah juga memiliki peranan yang penting dalam mempengaruhi kesiapan belajar siswa tunarungu, apabila sekolah dapat menciptakan hubungan dan komunikasi yang baik, menggunakan metode pembelajaran yang aktif-interaktif, mencukupi sarana penunjang pembelajaran, menciptakan suasana tertib dan disiplin, maka akan dapat mendorong kesiapan belajar para siswa dalam proses pembelajaran di sekolah (Slameto, 2013). Menurut Bronfrenbrenner (Berns, 2004) sekolah adalah mikrosistem dimana anak- anak secara formal belajar tentang lingkungan belajar mereka dan anak berinteraksi dalam suatu lingkungan atau 
komunitas yang signifikan. Guru mendorong pengembangan berbagai keterampilan dan perilaku dengan bertindak sebagai model peran serta memberikan motivasi bagi anak untuk siap dalam belajar. Sekolah inklusi tempat kedua subjek mengikuti proses belajar sudah memberikan dukungan yang besar bagi kedua subjek, yaitu dengan memberikan pelajaran tambahan khusus setelah pulang sekolah untuk kedua subjek dan siswa ABK lainnya agar mereka mampu untuk mengikuti pembelajaran di kelas dengan baik. Hal ini juga didukung dengan guru yang sudah kooperatif untuk mengayomi mereka di dalam kelas, selain itu sekolah juga meminjamkan buku paket penunjang belajar untuk bisa digunakan oleh siswa agar mereka bisa mengulang pelajaran yang dijelaskan oleh guru di sekolah.

Kedua subjek memiliki lingkungan pergaulan yang mampu untuk mendukung mereka secara baik. Teman-teman kedua subjek memiliki kepedulian yang tinggi dan sangat kooperatif membantu kedua subjek belajar di kelas. Teman bergaul pengaruhnya sangat besar dan lebih cepat masuk dalam jiwa anak. Teman bergaul yang baik akan berpengaruh baik terhadap belajar anak dan sebaliknya teman bergaul yang kurang baik akan berpengaruh kurang baik pula (Slameto, 2013). Menurut Bronfrenbrenner, teman juga merupakan bagian dari mikrosistem yaitu setting dimana anak-anak pada umumnya tanpa pengawasan orang dewasa akan saling berinteraksi. Manfaat memiliki teman adalah anak-anak bisa merasakan siapa diri mereka dan apa yang dapat dilakukan, dengan membandingkan dirinya dengan orang lain, hal ini akan saling memberikan dukungan, kelekatan, serta sumber pengalaman bekerja sama, sehingga lingkungan pergaulan yang baik akan menambah kesiapan belajar siswa di sekolah (Berns, 2004).
Berdasarkan pemaparan hasil diatas, menunjukkan bahwa kedua subjek sudah memiliki kesipan belajar. Kondisi yang mendukung kesiapan belajar subjek pertama berupa perhatian, bimbingan, dan kasih sayang dari orang tua, guru yang kooperatif, teman-teman yang membantu subjek untuk belajar, dan semangat dari diri subjek sendiri. Kondisi yang menghambat adalah rumah subjek yang jauh sehingga mengakibatkan subjek jarang berangkat sekolah.

Kondisi yang mendukung kesiapan belajar subjek kedua berupa dukungan tenaga, biaya, pikiran, bimbingan, perhatian dari orang tua dan usaha untuk memenuhi yang dibutuhkan dalam kegiatan belajar, guru yang kooperatif, dan teman-teman yang membantu subjek untuk belajar, sedangkan kondisi yang menghambat yaitu kemampuan bahasa yang kurang sehingga subjek terkadang sulit untuk memahami pelajaran di kelas.

Keluarga sebagai unit terkecil disarankan untuk lebih bisa menyempatkan waktu memberikan dukungan sosial berupa perhatian, kasih sayang, penghargaan, dan pertolongan kepada mereka ketika berada di rumah. Sekolah juga diharapkan dapat mempersiapkan guru yang akan mengajar siswa tunarungu di kelas, karena siswa tunarungu memerlukan cara pengajaran yang berbeda dengan siswa normal, guru juga diharapkan bisa memberikan standar penilaian yang berbeda dengan siswa normal dan disesuaikan dengan kemampuan akademik siswa ABK khususnya siswa tunarungu untuk memberikan pengalaman berhasil bagi mereka, serta menghadirkan guru pembimbing khusus (GPK) bagi siswa tunarungu lebih sering agar siswa tunarungu mampu mengikuti setiap proses pembelajaran secara baik dengan bimbingan GPK. 
Pemerintah juga diharapkan untuk lebih bisa melihat dan memenuhi kebutuhan ABK khususnya siswa tunarungu yang menempuh pendidikan di sekolah inklusi dan bisa menetapkan standar asesmen bagi para ABK terutama siswa tunarungu yang ingin masuk ke sekolah inklusi baik dari aspek akademik maupun perkembangannya, agar diketahui modalitas siswa berkenaan dengan kemampuan dan kebutuhannya dalam pembelajaran.

\section{Simpulan}

Kedua subjek sudah memiliki kesiapan belajar yang sebagaimana diharapkan. Subjek pertama yang mendapatkan dukungan berupa pemberian pemahaman terkait kondisi subjek, perhatian, bimbingan, kasih sayang, dan semangat dari orang tua, sekolah, dan teman-teman sehingga menghasilkan bentuk respon yang positif dari subjek, begitu juga dengan subjek kedua yang mendapatkan dukungan dari orang tua, sekolah, dan teman-teman berupa tenaga, biaya, pikiran, bimbingan, perhatian dan usaha untuk memenuhi apa yang dibutuhkan dalam kegiatan belajar subjek, sehingga subjek menghasilkan bentuk respon yang positif terhadap lingkungan subjek. Sekolah, guru dan pemerintah juga diharapkan dapat memberikan dukungan kepada ABK terutama anak tunarungu dalam hal yang dapat mendukung kesiapan belajar anak tunarungu seperti fasilitas dan kesiapan guru dalam mengajar ABK.

\section{Daftar Pustaka}

Berns, R. M. (2004). Child, family, school, community. $6^{\text {th }}$ ed. USA: Wadsworth

Direktorat Pembinaan Sekolah Luar Biasa. (2008). Pengadaan dan pembinaan tenaga kependididkan dalam pendidikan inklusif. Jakarta: Dit PSLB Depdiknas

Dirjen PLB. (2006). Pendidikan inklusif. Jakarta: Direktorat Pembinaan SLB Dirjen Dikdasmen

Djamarah, S. B. 2011. Psikologi belajar. Jakarta: PT Rineka Cipta

Efendi, M.(2008). Pengantarpsikopedagogik anak berkelainan. Cetakan kedua. Jakarta: Bumi Aksara

Ericks-Brophy, A., Durriex-Smith, A., Olds, J., Fitzpatrick, E., Duquette, C., Whittingham, J. (2006). Facilitators and barriers to the inclusion of orally educated children and youth with hearing loss in schools: promoting partnerships to support inclusion. The Volta Review; Spring 2006; 106, 1; ProQuest Nursing \& Allied Health Source pg. 53 - 88

Fusick, L. (2008). Serving clients with hearing loss: best practices in mental health counseling. Journal of Counseling and Development, 86, 1, 102

Haenudin. (2013). Pendidikan anak berkebutuhan khusus tunarungu. Jakarta: Luxima

Hancock, D.R. \& Algozzine, B. (2006). Doing case study research practical guide for beginning researchers. New York and London: Teachers College Columbia University

Moleong, L.J. (2010). Metodologi penelitian kualitatif. Bandung : PT Remaja Rosdakarya

Orr, A.C. \& Hammig, S.B. Inclusive postsecondary strategies for teaching 
students with learning disabilities: a review of the literature. Learning Disability Quarterly; Summer 2009, 32, 3; ProQuest Nursing \& Allied Health Source

Pemerintah Republik Indonesia. (2010). Undang-undang SISDIKNAS: Sistem pendidikan nasional. Bandung: Fokusmedia

Poerwandari, K. (2009). Pendekatan kualitatif. Cetakan ketiga. Depok: LPSP3 UI

Slameto. (2010). Belajar dan faktorfaktor yang mempengaruhinya. Jakarta: Rineka Cipta.

Smart, A. (2010). Anak cacat bukan kiamat: metode pembelajaran dan terapi untuk anak berkebutuhan khusus. Yogyakarta: Ar-Ruz Media.

Smith, D. J. (2006). Inklusi sekolah ramah untuk semua. Bandung: Nuansa.
Suara Merdeka. (2014). 1.926 ABK DIY belum tersentuh pendidikan.diunduh dari: http://berita.suaramerdeka. com/1-926-abk-diy-belum-tersentuhpendidikan. 21 Oktober 2014.

Sugiyono. (2011). Metode penelitian kuantitatif, kualitatif dan $R \& D$. Bandung: Alfabeta.

Thaghard, E.K., Hilsmier, A.S., \& Easterbrooks, S.R. (2011). Pragmatic language in deaf and hard of hearing students: correlation with success in general education. American Annals of The Deaf. Vol. 155, No.5, page 526 - 534

Winarsih, M. (2007). Intervensi dini bagi anak tunarungu dalam pemerolehan bahasa. Jakarta: De pdikbud. 